\title{
Dampak Kebijakan Perberasan pada Pasar Beras dan Kesejahteraan Produsen dan Konsumen Beras di Indonesia
}

\section{(The Impact of Rice Policy on Rice Market and The Welfare of Rice Producers and Consumers in Indonesia)}

\author{
Edy Siswanto $^{1^{\star}}$, Bonar Marulitua Sinaga $^{2}$, Harianto $^{3}$
}

(Diterima Juli 2017/Disetujui Mei 2018)

\begin{abstract}
ABSTRAK
Permintaan beras di Indonesia meningkat setiap tahunnya sehingga membuat kesenjangan semakin besar antara produksi dan konsumsi. Kelebihan permintaan ditutupi oleh impor beras yang menyebabkan harga beras dalam negeri merespons pergerakan harga beras global yang merugikan produsen dan konsumen. Jadi, instrumen kebijakan yang dapat mengurangi ketergantungan pada beras impor dan memberi keuntungan kepada produsen dan konsumen beras sangat dibutuhkan. Tujuan penelitian ini adalah untuk menganalisis dampak kebijakan beras pada pasar beras dan kesejahteraan produsen dan konsumen beras di Indonesia. Penelitian ini menggunakan data time series tahunan dan model persamaan simultan dengan metode two stage least squares. Analisis menunjukkan bahwa perubahan kebijakan beras dapat memengaruhi kondisi pasar beras Indonesia dan kenaikan harga pembelian pemerintah (HPP), kredit pertanian, dan subsidi pupuk dapat meningkatkan kesejahteraan produsen dan konsumen.
\end{abstract}

Kata kunci: ekspor, impor, kebijakan perberasan, kesejahteraan, pasar beras

\section{ABSTRACT}

Rice demand in Indonesia increases every year so it makes the big gap between production and consumption of rice. Excess demand is covered by rice import which causes domestic rice price responds the global rice price movements that harm both producers and consumers. So, the policy instruments that could reduce dependence on rice import and can provide benefits to producers and consumers of rice is very needed. The objectives of this study were to analyze the impact of rice policy on rice market and the welfare of rice producers and consumers. This study uses annual time series data and simultaneous equations model with two stages least squares method. The analysis showed that rice policy changes can influence condition of Indonesia's rice market and that the increase in Government Purchase Price (HPP), agricultural credit, and fertilizer subsidy can improve the welfare of the producers and consumers.

Keywords: export, import, rice market, rice policy, welfare

\section{PENDAHULUAN}

Beras adalah komoditas pangan utama yang memengaruhi kesejahteraan masyarakat Indonesia (Septiadi 2016). Sekitar 98\% penduduk Indonesia mengkonsumsi beras sebagai makanan pokok (Riyad 2002), bahkan menurut Mardianto \& Mewa (2004), di beberapa daerah yang secara tradisional memiliki pangan utama jagung atau sagu, sebagian penduduknya telah beralih mengonsumsi beras. Beras juga

1 Sekolah Pascasarjana, Fakultas Ekonomi dan Manajemen, Institut Pertanian Bogor, Kampus IPB Darmaga, Bogor 16680.

2 Departemen Ekonomi dan Sumberdaya Lingkungan, Fakultas Ekonomi dan Manajemen, Institut Pertanian Bogor, Kampus IPB Darmaga, Bogor 16680.

3 Departemen Agribisnis, Fakultas Ekonomi dan Manajemen, Institut Pertanian Bogor, Kampus IPB Darmaga, Bogor 16680.

* Penulis Korespondensi: E-mail: e.dhy.math45@gmail.com merupakan komoditas dengan permintaan yang inelastis, artinya perubahan harga tidak menyebabkan perubahan jumlah permintaan konsumen dan apabila ketersediaan berkurang akan mengakibatkan harga melambung tinggi sehingga tidak terjangkau oleh konsumen (Abidin 2015). Isu keamanan pangan sebagai spillover effects ditandai dengan lonjakan harga pangan di tingkat konsumen di seluruh dunia. Peningkatan harga pangan ini menjadi beban bagi masyarakat miskin di negara berkembang yang menghabiskan rata-rata setengah dari pendapatan rumah tangga untuk kebutuhan pangan, terutama pada komoditas serealia (padi-padian) (Busnita 2016; Miranti et al. 2016). Komoditas beras juga merupakan komoditas strategis dalam pembangunan nasional (Akhmad 2014; Rahmasuciana et al. 2015; Wahid 2015; Zaeroni et al. 2016). Nilai strategis beras dilihat dari dua sisi, yaitu 1) Sebagai pangan utama beras harus tersedia dalam jumlah yang cukup untuk memenuhi kebutuhan masyarakat dan 2) Sebagai sumber pendapatan dan lapangan kerja bagi sebagian besar masyarakat 
Indonesia terutama masyarakat perdesaan. Hal ini menjadikan beras sebagai salah satu cost push inflation factor.

Produksi beras Indonesia berhasil ditingkatkan pada tahun 2010-2014 sebesar 4,4 juta ton. Hal ini didukung oleh peningkatan luas areal pertanian dan produktivitas petani (BPS 2016). Hal itu juga diikuti oleh pertumbuhan penduduk yang semakin meningkat pula. Menurut BPS (2015), jumlah pertambahan penduduk Indonesia dari tahun 2010-2014 sebanyak 13,7 juta jiwa dan tingkat konsumsi rata-rata per kapita seminggu beras sebesar $1,73 \mathrm{~kg}$ sehingga mengakibatkan konsumsi beras melebihi produksi. Dewasa ini swasembada terus diupayakan dan menjadi salah satu prioritas kebijakan pemerintah, meskipun konsep swasembada telah berubah dengan adanya keterbukaan kemungkinan impor sampai batas tertentu. Konsep ini disebut self-sufficiency-on trade (Sapuan 1999). Kebijakan impor beras juga dapat menstabilkan harga beras dalam waktu yang relatif singkat sehingga dapat dijadikan alternatif untuk menurunkan harga beras agar terjangkau oleh daya beli konsumen (Widiarsih 2012). Pemerintah perlu juga memperhatikan karakteristik pasar beras yang "tipis" (jarang diperdagangkan) dan kondisi jumlah produksi dan harga yang berfluktuasi. Hal ini akan membuat harga beras domestik terintegrasi dengan kondisi negara eksportir (Edi et al. 2014).

Tingkat konsumsi yang melebihi produksi beras saat ini mendorong pemerintah untuk melakukan impor melalui perdagangan beras dunia. USDA (2015) mengemukakan bahwa negara Thailand, India, dan Vietnam merupakan negara eksportir utama beras dunia dengan share $65,01 \%$, sedangkan China, Nigeria, Filipina, dan Indonesia merupakan negara importir beras dunia dengan share sebesar $23,96 \%$. Indonesia merupakan negara importir ketiga beras dunia setelah Filipina dan China. Impor beras Indonesia berasal dari 3 negara utama, yaitu Vietnam, Thailand, dan India. Besaran persentasi masing-masing adalah Vietnam 53,02\%, Thailand $29,07 \%$, dan India 9,61\% (USDA 2015). Hal ini menunjukkan bahwa kondisi perberasan di ketiga negara tersebut sangat berpengaruh pada kondisi perberasan domestik.

Penerapan kebijakan liberalisasi perdagangan secara penuh di sektor perberasan mengakibatkan penurunan produksi, tenaga kerja, kesejahteraan petani, dan neraca perdagangan (Rosandi 2016). Hal ini menunjukkan bahwa menggantungkan pemenuhan kebutuhan beras domestik pada beras impor bukan merupakan keputusan yang tepat bagi pemerintah. Penerapan kebijakan proteksi penuh sektor beras dapat meningkatkan produksi beras dan tenaga kerja. Hal ini menunjukkan bahwa kebutuhan beras domestik dalam jangka panjang dapat terpenuhi oleh produksi beras dalam negeri. Peningkatan produksi beras domestik harus dapat didukung oleh pemerintah melalui kebijakan-kebijakan yang efektif, sehingga dengan meningkatnya produksi beras dapat meningkatkan kesejahteraan produsen maupun konsumen beras. Instrumen kebijakan yang telah dilakukan oleh pemerintah di antaranya penjaminan harga gabah melalui kebijakan Harga Pembelian Pemerintah (HPP), pemberian bantuan berupa kredit pertanian dengan bunga rendah, dan bantuan input berupa subsidi pupuk, subsidi benih, dan subsidi pestisida (Dabukke et al. 2014).

Kebijakan dan intervensi pemerintah secara penuh terus diupayakan untuk mencapai swasembada beras, namun penawaran, permintaan, dan harga beras demikian dinamis. Dinamika tersebut mengakibatkan kondisi pasar beras domestik yang tidak seimbang sehingga menjadikan kesejahteraan produsen dan konsumen beras di Indonesia menjadi hal yang sulit untuk diwujudkan oleh pemerintah. Oleh sebab itu, menjadi menarik untuk mengkaji dampak kebijakan perberasan yang ditetapkan dalam Inpres No. 13 tahun 2005 pada pasar beras domestik dan kesejahteraan produsen serta konsumen beras di Indonesia.

Selama ini, efektivitas penerapan kebijakan perberasan masih relatif rendah, seperti terjadi pada kebijakan subsidi pupuk yang secara kumulatif lebih banyak dinikmati oleh petani besar dan produsen pupuk (Sudaryanto et al. 2016). Hal ini menjadi koreksi bagi pemerintah untuk meninjau kembali efektivitas kebijakan yang telah dilakukan agar kebijakan tersebut dapat menjaga ketersediaan beras di Indonesia sehingga kesejahteraan masyarakat Indonesia dapat terwujudkan.

Berdasarkan permasalahan tersebut, maka tujuan penelitian ini adalah untuk menganalisis dampak perubahan kebijakan perberasan pada pasar beras dan kesejahteraan masyarakat di Indonesia. Ruang lingkup penelitian ini meliputi pasar beras dunia (3 negara eksportir utama dan importir utama), pasar beras domestik (tingkat konsumen dan petani). Kebijakan perberasan meliputi Harga Pembelian Pemerintah (HPP), kredit pertanian, dan subsidi pupuk.

\section{METODE PENELITIAN}

\section{Jenis dan Sumber Data}

Penelitian ini menggunakan data sekunder berupa data deret waktu (time series) tahunan selama kurun waktu 34 tahun (tahun 1981 hingga tahun 2014). Pemilihan data time series disesuaikan dengan tujuan penelitian, yaitu untuk menguji teoretik, melihat kejelasan suatu hubungan antara variabel endogen dan variabel penjelas, serta melihat dampak dari suatu perubahan kebijakan (Musianto 2002). Data penelitian bersumber dari beberapa instansi terkait, yaitu Badan Pusat Statistik (BPS), Badan Urusan Logistik (Bulog), dan Kementerian Pertanian. Kelengkapan dan penyesuaian data juga dilakukan dengan pengumpulan data dari beberapa publikasi seperti FAO (Food Agricultural Organization), IRRI (International Rice Risearch Institute), Bank Dunia (World Bank), WTO (World Trade Organization), UNComtrade, dan USDA (United State Department of Agriculture). 


\section{Metode Analisis}

Analisis dilakukan dengan menggunakan model ekonometrika dalam bentuk sistem persamaan simultan yang terdiri atas 21 persamaan, yaitu 16 persamaan perilaku (struktural) dan 5 persamaan identitas. Model yang digunakan telah terlebih dahulu melalui tahapan respesifikasi model guna memenuhi kriteria ekonomi, statistik, dan ekonometrika (Koutsoyianis 1977). Analisis kondisi pasar ditentukan oleh faktor permintaan, penawaran, dan harga, sedangkan kesejahteraan masyarakat ditentukan oleh indikator surplus produsen dan konsumen.

Model perdagangan beras Indonesia yang dibangun terdiri atas dua blok, yaitu blok pasar beras domestik dan dunia. Secara matematis persamaannya adalah sebagai berikut:

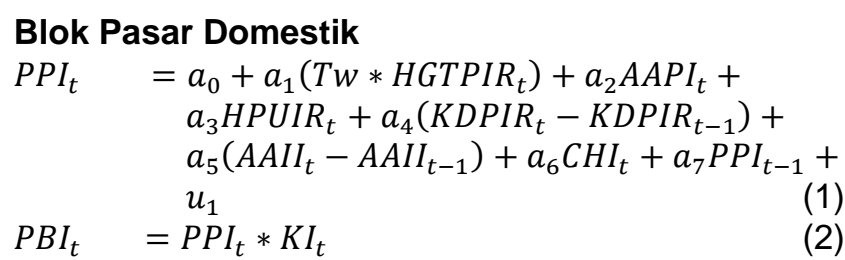

$J I B I T_{t}=b_{0}+b_{1}\left(H I B I R_{t}-H I B I R_{t-1}\right)+b_{2}\left(N T I T R_{t}-\right.$ NTITR $\left._{t-1}\right)+b_{3} D B I_{t}+b_{4}\left(P B I_{t}-P B I_{t-1}\right)+$ $b_{5} S T K B I_{t-1}+b_{6} J I B I T_{t-1}+$

$u_{2} \quad$ (3)

$J I B I A_{t}=c_{0}+c_{1}\left(\frac{\text { HIBIR }_{t}}{\text { HIBIR }_{t-1}}\right)+c_{2} N T I A R_{t}+c_{3}\left(D B I_{t}-\right.$ $\left.D B I_{t-1}\right)+c_{4} P B I_{t}+c_{5} S T K B I_{t-1}+$ $c_{6} J I B I A_{t-1}+u_{3}$

$J I B I V_{t}=d_{0}+d_{1}\left(H I B I R_{t}-H I B I R_{t-1}\right)+d_{2} N_{T I V R}+$ $d_{3} D B I_{t}+d_{4}\left(P B I_{t}-P B I_{t-1}\right)+$ $d_{5} S T K B I_{t-1}+d_{6} J I B I V_{t-1}+u_{4}$

$T I B I_{t}=J I B I T_{t}+J I B I A_{t}+J I B I V_{t}+J I B I N L_{t}$

$S T K B I_{t}=e_{0}+e_{1} H B E I R_{t}+e_{2} P G B B I_{t}+e_{3} O P S I_{t}+$ $e_{4} T I B I_{t}+e_{5} S T K B I_{t-1}+u_{5}$

$S B I_{t} \quad=P B I_{t}+S T K B I_{t-1}+T J I B I_{t}$

$D B I_{t}=f_{0}+f_{1} H B E I R_{t}+f_{2} H_{J E I R_{t}}+f_{3} G D P I R_{t}+$ $f_{4} J P I_{t}+f_{5} D B I_{t-1}+u_{6}$

$H_{I B I R_{t}}=g_{0}+g_{1} H_{B D R}+g_{2}$ NTIR $_{t}+g_{3} H_{I B I R_{t-1}}+$ $u_{7}$

HBEIR $R_{t}=h_{0}+h_{1}$ HIBIR $_{t}+h_{2}$ HGTPIR $_{t}+h_{3} D B I_{t}+$ $h_{4} S B I_{t-1}+h_{5} T I_{t}+h_{6} H B E I R_{t-1}+u_{8}$

$H_{G T P I R_{t}}=i_{0}+i_{1} H B E I R_{t}+i_{2}\left(T w * H P P I R_{t}\right)+$ $i_{3}\left(P P I_{t}-P P I_{t-1}\right)+i_{4} H G T P I R_{t-1}+u_{9}$

\section{Blok Pasar Dunia}

$J X B T_{t}=j_{0}+j_{1}\left(H B D R_{t}-H B D R_{t-1}\right)+j_{2} N T T R_{t}+$ $j_{3} P B T_{t}+j_{4}\left(\frac{S T K B T_{t}}{S T K B T_{t-1}}\right)+j_{5} J X B T_{t-1}+$ $u_{10}$

$J X B A_{t}=k_{0}+k_{1}\left(H B D R_{t-1} * N T A R_{t-1}\right)+k_{2} P B A_{t}+$ $k_{3} S T K B A_{t-1}+k_{4} J X B A_{t-1}+u_{11}$

$J X B V_{t}=l_{0}+l_{1} H B D R_{t}+l_{2} N T V R_{t}+l_{3} P B V_{t}+$ $l_{4} S T K B V_{t-1}+l_{5} J X B V_{t-1}+u_{12}$

$J I B C_{t}=m_{0}+m_{1} H B D R_{t-1}+m_{2}\left(\frac{K B C_{t}}{J P C_{t}}\right)+m_{3} P B C_{t}+$ $m_{4} G D P C R_{t}+m_{5}\left(N T C R_{t}-N T C R_{t-1}\right)+$

$m_{6} S T K B C_{t-1}+m_{7} J I B C_{t-1}+u_{13}$

$$
\begin{aligned}
J I B N_{t}= & n_{0}+n_{1}\left(H B D R_{t} * N T N R_{t}\right)+n_{2}\left(\frac{K B N_{t}}{J P N_{t}}\right)+ \\
& n_{3} P B N_{t-1}+n_{4}\left(G D P N R_{t}-G D P N R_{t-1}\right)+ \\
& n_{5} J I B N_{t-1}+u_{14} \\
J I B F_{t}= & o_{0}+o_{1}\left(H B D R_{t} * N T F R_{t}\right)+o_{2}\left(\frac{K B F_{t}}{J P F_{t}}\right)+ \\
& o_{3} P B F_{t}+o_{4} G D P F R_{t-1}+o_{5} S T K B F_{t-1}+ \\
& u_{15} \\
J X D_{t}= & J X B T_{t}+J X B A_{t}+J X B V_{t}+J X B N L_{t} \\
J I D_{t}= & T J I B I_{t}+J I B C_{t}+J I B N_{t}+J I B F_{t}+ \\
& J I B N L_{t} \\
H B D R_{t}= & p_{0}+p_{1} J X D_{t}+p_{2} J I D_{t}+p_{3} H M M D R_{t}+ \\
& p_{4} H B D R_{t-1}+u_{16}
\end{aligned}
$$

Keterangan:

Variabel Endogen

$\mathrm{PPI}_{t} \quad$ : Produksi padi Indonesia tahun ke t (000 ton)

$\mathrm{PBI}_{t} \quad$ : Produksi beras Indonesia tahun ke $\mathrm{t}(000 \mathrm{ton})$

$J I B I T_{t}$ : Jumlah impor beras dari Thailand (000 ton)

$J I B I A_{t}$ : Jumlah impor beras dari India (000 ton)

$J I B I V_{t}$ : Jumlah impor beras dari Vietnam (000 ton)

TJIBI $_{t}$ : Total jumlah impor beras Indonesia (000 ton)

$S T K B I_{t}:$ Stok beras di Indonesia (000 ton)

$S B I_{t} \quad$ : Penawaran beras Indonesia (000 ton)

$D B I_{t} \quad$ : Pemintaan beras di Indonesia (000 ton)

$H I B I R_{t}$ : Harga impor beras Indonesia riil (US\$/kg)

$H B E R I_{t}$ : Harga beras eceran riil Indonesia ( $\left.\mathrm{Rp} / \mathrm{kg}\right)$

$H G T P I R_{t}$ : Harga gabah tingkat petani (US\$ $\left./ \mathrm{kg}\right)$

$J X B T_{t}$ : Jumlah ekspor beras Thailand (000 ton)

$J X B A_{t}$ : Jumlah ekspor beras India (000 ton)

$J X B V_{t}$ : Jumlah ekspor beras Vietnam (000 ton)

$J X D_{t} \quad$ : Jumlah ekspor beras Dunia (000 ton)

$J I B C_{t}$ : Jumlah impor beras China (000 ton)

$J I B N_{t}$ : Jumlah impor beras Nigeria (000 ton)

$J I B F_{t}$ : Jumlah impor beras Filipina (000 ton)

$J I D_{t} \quad$ : Jumlah impor beras Dunia (000 ton)

$H B D R_{t}$ : Harga beras dunia riil (US\$/kg)

\section{Variabel Eksogen}

$A A P I_{t} \quad$ : Luas areal panen di Indonesia (000 ha)

$H P U I_{t}$ : Harga pupuk urea riil Indonesia (US\$/kg)

$K D P I_{t} \quad:$ Kredit pertanian riil Indonesia (US\$ juta)

$A_{A I I_{t}} \quad$ : Luas areal irigasi Indonesia (000 ha)

$\mathrm{CHI}_{t} \quad$ : Curah hujan Indonesia (mm/tahun)

$\mathrm{Tw}_{t} \quad$ : Tren waktu

$K I_{t} \quad$ : Faktor konversi Indonesia

NTIT $_{t} \quad$ : Nilai tukar Inonesia terhadap Thailand (Rp/Bath)

NTIA $_{t}$ : Nilai tukar Inonesia terhadap India (Rp/Rupee)

$N T I V_{t}$ : Nilai tukar Inonesia terhadap Vietnam (Rp/Dong)

$J I B I N L_{t}$ : Jumlah impor beras Indonesia dari negara lainnya (000 ton)

$\mathrm{PGBBI}_{t}$ : Pengadaan gabah Indonesia (000 ton)

OPSI $_{t}$ : Operasi pasar Indonesia (000 ton)

$H J E R I_{t}$ : Harga jagung eceran riil Indonesia $(\mathrm{Rp} / \mathrm{kg})$

$G D P R I_{t}$ : GDP riil di Indonesia (US\$)

$J P I_{t} \quad$ : Jumlah penduduk Indonesia (000 jiwa)

$N T I_{t} \quad$ : Nilai tukar Indonesia (Rp/US\$) 


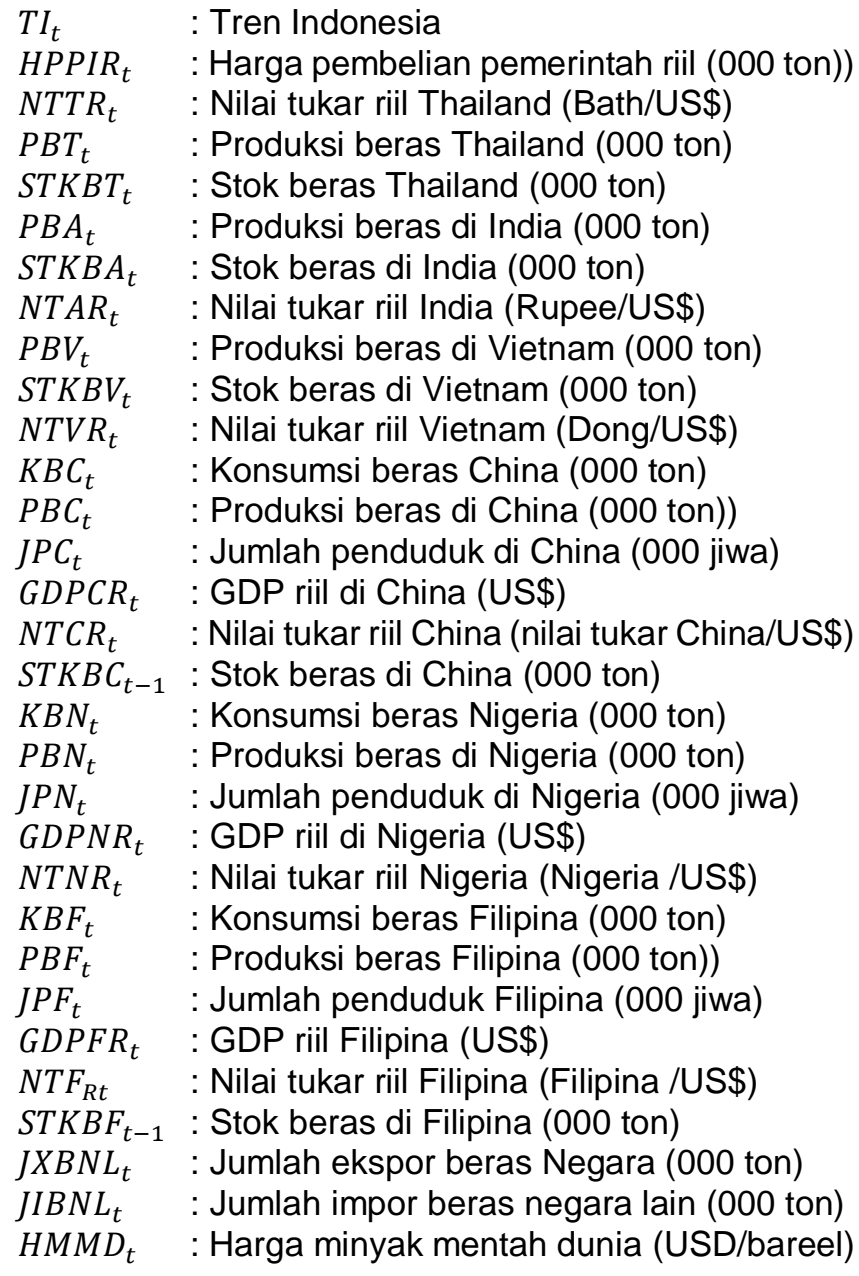

\section{HASIL DAN PEMBAHASAN}

Model perdagangan beras Indonesia merupakan model linear persamaan simultan dan diestimasi dengan metode two stage least squares (2SLS) menunjukkan indikator statistik yang baik. Hal tersebut terlihat dari koefisien determinasi $\left(R^{2}\right)$, yaitu sebanyak $69 \%$ dari persamaan perilaku yang mempunyai koefisien determinasi $\left(R^{2}\right)$ lebih dari $63 \%$, sedangkan $31 \%$ dari persamaan perilaku memiliki koefisien determinasi berkisar antara $13-54 \%$. Hal ini menunjukkan bahwa secara umum variabel-variabel penjelas (explanatory variable) yang ada dalam persamaan perilaku mampu menjelaskan dengan baik variabel endogen (endogenous variable).

Persentase sebanyak $81,25 \%$ dari jumlah persamaan perilaku, memiliki nilai statistik $\mathrm{F}$ nyata dalam taraf $1 \%$. Hal tersebut menunjukkan bahwa variabelvariabel penjelas dalam persamaan perilaku secara bersama-sama berpengaruh nyata pada variabel endogennya. Selain itu, hanya $18,75 \%$ yang berada pada taraf nyata berkisar antara $2-38 \%$. Setiap persamaan struktural mempunyai besaran parameter dan tanda (magnitude dan sign) sesuai dengan hipotesis dan logis dari sudut pandang ekonomi.

Nilai statistik $t$ digunakan untuk menguji apakah masing-masing variabel penjelas berpengaruh nyata pada variabel endogennya. Berdasarkan nilai statistik $\mathrm{t}$, terdapat variabel penjelas yang tidak signifikan pada berbagai taraf $\alpha=0,05-0,20$ yang ditoleransi, namun yang diutamakan pada penelitian ini adalah kelogisan dan kesesuaian tanda dan besaran (sign dan magnitude) dengan kriteria ekonomi. Berdasarkan kriteria tersebut, dengan mempertimbangkan periode pengamatan yang cukup panjang maka hasil estimasi model dalam penelitian ini dapat dikatakan cukup mendeskripsikan fenomena pasar beras di Indonesia.

Indikator validasi statistik yang digunakan adalah Root Mean Square Percent Error (RMSPE) dan UTheil's. Model tersebut menunjukkan bahwa 16 persamaan dalam model memiliki nilai RMSPE antara 1$88 \%$ dan 5 persamaan memiliki RMSPE $>100 \%$. Berdasarkan kriteria U-Theil, terdapat 17 persamaan memiliki nilai $U$-Theil $<0,30$ dan 4 persamaan memiliki nilai U-Theil $>0,30$. Berdasarkan kondisi tersebut dapat disimpulkan bahwa persamaan di dalam model memiliki daya prediksi yang baik.

\section{Simulasi Dampak Kebijakan Perberasan pada Pasar Beras}

Karakteristik pasar beras yang tipis dan merupakan pasar residual menyebabkan perubahan harga beras dunia menjadi faktor penting yang menentukan kesejahteraan masyarakat (Hidayat 2012). Oleh sebab itu, dilakukan beberapa simulasi perubahan kebijakan perberasan yang dapat dijadikan solusi atas dampak gejolak harga dunia dalam memengaruhi kondisi pasar beras domestik dan kesejahteraan masyarakat Indonesia.

Permintaan beras di Indonesia terus meningkat sehingga kesenjangan antara produksi dan konsumsi terus membesar. Kelebihan permintaan tersebut dipenuhi oleh beras impor yang menyebabkan harga beras domestik mengikuti pergerakan harga beras dunia yang merugikan masyarakat Indonesia. Adanya solusi jangka panjang berupa kebijakan yang mendukung peningkatan produksi beras domestik diperlukan untuk memenuhi permintaan beras tersebut (Nuryanti 2005). Menurut Office of the United States Trade Representative (2015), salah satu yang menjadi faktor utama dalam menentukan produksi beras negara eksportir yang memiliki pertumbuhan positif adalah penerapan kebijakan subsidi kredit pertanian, subsidi input, dan penjaminan harga. Kebijakan perberasan di negara eksportir tersebut harus dijadikan contoh oleh pemerintah jika ingin meningkatkan produksi beras domestik.

Tabel 1 menunjukkan bahwa simulasi peningkatan kredit pertanian (simulasi 1) mendorong petani untuk peningkatan produksi padi. Peningkatan produksi padi diikuti oleh peningkatan produksi beras dengan besaran yang sama, yaitu sebesar $0,24 \%$. Peningkatan produksi padi menjadikan para tengkulak dengan mudah mempermainkan harga sehingga mengakibatkan harga gabah tingkat petani menurun sebesar $0,53 \%$. Peningkatan produksi beras menyebabkan penawaran di pasar beras domestik berlebih sehingga harga beras eceran turun dan daya beli konsumen 
Tabel 1 Dampak kebijakan perberasan pada pasar beras 2010-2014

\begin{tabular}{|c|c|c|c|c|c|c|}
\hline \multirow{2}{*}{ Nama variabel } & \multirow{2}{*}{ Satuan } & \multirow{2}{*}{ Basis } & \multicolumn{4}{|c|}{ Simulasi (\% perubahan) } \\
\hline & & & 1 & 2 & 3 & 4 \\
\hline Produksi padi Indonesia & 000 ton & $68.535,7000$ & 0,2406 & 0,2394 & 0,0690 & 0,5491 \\
\hline Produksi beras Indonesia & 000 ton & $43.177,5000$ & 0,2406 & 0,2395 & 0,0690 & 0,5491 \\
\hline $\begin{array}{l}\text { Jumlah impor beras Indonesia dari } \\
\text { Thailand }\end{array}$ & 000 ton & 450,4000 & $-0,3774$ & $-0,3330$ & $-0,2220$ & $-0,9547$ \\
\hline $\begin{array}{l}\text { Jumlah impor beras Indonesia dari } \\
\text { India }\end{array}$ & 000 ton & 82,2500 & $-0,6044$ & $-0,6436$ & $-0,4264$ & $-1,6744$ \\
\hline $\begin{array}{l}\text { Jumlah impor beras Indonesia dari } \\
\text { Vietnam }\end{array}$ & 000 ton & 572,9000 & $-0,5760$ & $-0,5062$ & $-0,4364$ & $-1,5186$ \\
\hline Total jumlah impor beras Indonesia & 000 ton & $1.179,8000$ & $-0,4747$ & $-0,4238$ & $-0,3306$ & $-1,2205$ \\
\hline Stok beras Indonesia & 000 ton & $1.550,5000$ & 0,1290 & 0,1419 & $-0,3741$ & $-0,0903$ \\
\hline Penawaran beras Indonesia & 000 ton & $45.981,0000$ & 0,2162 & 0,2170 & 0,0478 & 0,4813 \\
\hline Permintaan beras Indonesia & 000 ton & $38.745,1000$ & 0,0981 & 0,1043 & $-0,1802$ & 0,0222 \\
\hline Harga impor beras impor Indonesia & USD/kg & 0,2294 & $-0,0436$ & $-0,0436$ & 0,0000 & $-0,0872$ \\
\hline Harga beras eceran Indonesia & $\mathrm{Rp} / \mathrm{kg}$ & $7.614,8000$ & $-0,7065$ & $-0,7420$ & 1,3067 & $-0,1431$ \\
\hline Harga gabah tingkat petani & $\mathrm{Rp} / \mathrm{kg}$ & $3.597,4000$ & $-0,5337$ & $-0,5532$ & 1,1647 & 0,0778 \\
\hline Jumlah ekspor beras Thailand & 000 ton & $9.232,0000$ & 0,0000 & 0,0000 & 0,0000 & 0,0000 \\
\hline Jumlah ekspor beras India & 000 ton & $6.693,9000$ & 0,0000 & 0,0000 & 0,0000 & 0,0000 \\
\hline Jumlah ekspor beras Vietnam & 000 ton & $5.736,5000$ & 0,0000 & 0,0000 & 0,0000 & $-0,0017$ \\
\hline Jumlah ekspor beras dunia & 000 ton & $36.030,9000$ & $-0,0003$ & $-0,0003$ & 0,0000 & $-0,0006$ \\
\hline Jumlah impor beras China & 000 ton & $1.655,1000$ & 0,0000 & 0,0000 & 0,0000 & 0,0000 \\
\hline Jumlah impor beras Nigeria & 000 ton & 699,5000 & 0,0000 & 0,0000 & 0,0000 & 0,0143 \\
\hline Jumlah impor beras Filipina & 000 ton & $1.158,9000$ & 0,0000 & 0,0000 & 0,0000 & 0,0086 \\
\hline Jumlah impor beras dunia & 000 ton & $39.502,6000$ & $-0,0139$ & $-0,0124$ & $-0,0099$ & $-0,0362$ \\
\hline Harga beras dunia & USD/kg & 0,0316 & $-0,3165$ & $-0,3165$ & $-0,3165$ & $-0,9494$ \\
\hline
\end{tabular}

semakin meningkat sebesar $0,10 \%$. Peningkatan produksi beras domestik menurunkan jumlah impor Indonesia sebesar 0,48\%. Penurunan jumlah impor Indonesia mengakibatkan jumlah impor beras dunia menurun dan akhirnya dengan menurunnya permintaan akan beras dunia maka harga beras turun sebesar $0,32 \%$. Penurunan harga beras dunia mengakibatkan penurunan jumlah ekspor beras dunia dengan jumlah yang sangat kecil, yaitu sebesar $0,0003 \%$. Penurunan jumlah impor beras dunia, harga beras dunia, dan jumlah ekspor beras dunia tidak memengaruhi jumlah ekspor di negara eksportir maupun jumlah impor di negara importir. Hal ini menunjukkan bahwa Indonesia merupakan negara kecil dalam perdagangan beras dunia.

Simulasi kebijkan peningkatan subsidi pupuk (simulasi 2) memiliki dampak yang hampir sama dengan simulasi kebijakan peningkatan kredit pertanian (simulasi 1) karena kedua simulasi tersebut merupakan kebijakan subsidi input yang dapat dijadikan insentif petani untuk meningkatkan produksinya. Peningkatan subsidi pupuk dijadikan petani untuk meningkatkan jumlah produksi padi dan diikuti dengan peningkatan produksi beras dengan besaran yang sama, yaitu $0,24 \%$. Produksi padi yang melimpah menjadikan harga gabah ditingkat petani turun sebesar $0,55 \%$. Hal ini terjadi karena tidak ada jaminan harga dari pemerintah, sehingga harga gabah ditentukan oleh mekanisme pasar dengan kelebihan penawaran sebesar 0,22\%. Kondisi pasar beras domestik dengan kelebihan penawaran mengakibatkan harga beras eceran turun sebesar $0,74 \%$. Penurunan harga beras eceran menjadikan para konsumen beras bergerak untuk meningkatkan permintaan mereka sebesar $0,10 \%$, sehingga konsumen dapat mencukupi kebu- tuhan konsumsi beras dengan harga yang terjangkau. Penurunan harga beras eceran menggerakkan bulog untuk menyerap kelebihan beras di pasar untuk meningkatkan stok beras sebesar 0,14\%. Peningkatan stok dapat dipenuhi dengan menyerap produksi beras domestik sehingga pemerintah mengurangi jumlah impor beras Indonesia sebesar $0,42 \%$. Penurunan jumlah impor Indonesia mengakibatkan jumlah impor beras dunia menurun dan akhirnya dengan penurunan permintaan akan beras dunia maka harga beras dunia turun sebesar $0,32 \%$.

Simulasi peningkatan HPP (simulasi 3) mengakibatkan harga gabah tingkat petani meningkat sebesar $1,17 \%$ sehingga menjadi insentif bagi petani untuk meningkatkan produksi padi. Peningkatan produksi padi diikuti oleh peningkatan produksi beras dengan besaran yang sama, yaitu $0,07 \%$. Peningkatan harga gabah ditingkat petani ditransmisikan ke harga beras eceran yang juga meningkat sebesar 1,31\%. Harga beras eceran yang semakin mahal mengakibatkan permintaan beras menurun karena konsumen semakin tidak mampu membelinya. Pasar beras dunia, peningkatan produksi beras domestik menurunkan jumlah impor Indonesia sebesar 0,33\%. Indonesia merupakan negara besar dalam perdagangan beras, berkurangnya jumlah impor Indonesia mengakibatkan jumlah impor beras dunia menurun dan akhirnya dengan penurunan permintaan akan beras dunia maka harga beras turun sebesar $0,32 \%$.

Alternatif paket kebijakan peningkatan HPP, peningkatan kredit pertanian, dan peningkatan subsidi pupuk (simulasi 4) memberikan jaminan harga beserta dua jaminan input sekaligus berupa kredit dan subsidi pupuk. Peningkatan kredit pertanian dan subsidi pupuk memberikan insentif bagi petani untuk meningkatkan 
produksi padi sebesar $0,55 \%$, sedangkan peningkatan HPP mengakibatkan peningkatan harga gabah di tingkat petani sebesar $0,08 \%$. Hal ini menunjukkan bahwa jika kebijakan jaminan harga berupa HPP diterapkan bersamaan dengan kebijakan subsidi input semakin memberikan semangat bagi petani untuk meningkatkan produksinya (jika dibandingkan dengan penerapan salah satu kebijakan saja). Peningkatan produksi padi diikuti oleh peningkatan produksi beras dengan besaran yang sama, yaitu sebesar $0,55 \%$. Peningkatan produksi beras mengakibatkan penawaran di pasar beras domestik meningkat sebesar $0,48 \%$, peningkatan penawaran di pasar beras domestik mengakibatkan harga beras eceran turun sebesar $0,14 \%$, walaupun harga gabah di tingkat petani meningkat. Hal ini menunjukkan bahwa peningkatan penawaran cukup besar sehingga lebih berpengaruh pada harga eceran daripada harga gabah di tingkat petani. Kondisi penawaran meningkat dan harga beras eceran menurun mengakibatkan permintaan beras di pasar domestik meningkat sebesar $0,02 \%$. Pada pasar beras dunia, peningkatan produksi beras domestik menurunkan jumlah impor Indonesia sebesar $1,22 \%$. Indonesia merupakan negara besar dalam perdagangan beras. Berkurangnya jumlah impor Indonesia mengakibatkan jumlah impor beras dunia menurun dan akhirnya dengan penurunan permintaan akan beras dunia maka harga beras turun sebesar $0,95 \%$.

\section{Simulasi Dampak Kebijakan Perberasan pada Kesejahteraan Produsen dan Konsumen Beras}

Pemerintah bertujuan untuk meningkatkan kesejahteraan produsen dan konsumen beras. Setiap kebijakan yang dilakukan diarahkan untuk memaksimalkan kesejahteraan produsen maupun konsumen. Kesejahteraan dapat digambarkan melalui surplus produsen dan konsumen. Semakin meningkat surplus produsen menunjukkan petani semakin sejahtera, sedangkan semakin meningkat surplus konsumen menunjukkan konsumen beras semakin sejahtera.

Beberapa instrumen kebijakan perberasan yang dilakukan pemerintah untuk menjamin kesejahteraan masyarakat meliputi jaminan harga dan subsidi input seperti terlihat pada Tabel 2. Kebijakan subsidi input meliputi peningkatan kredit pertanian dan subsidi pupuk. Peningkatan kredit pertanian (simulasi 1) menyebabkan peningkatan produksi padi, tetapi dengan peningkatan produksi padi mengakibatkan harga gabah di tingkat petani turun sehingga merugikan produsen. Kerugian produsen terlihat dari penurunan surplus produsen sebesar Rp1.317,47 miliar. Berbeda dari produsen, penurunan harga gabah mengakibatkan penurunan harga beras eceran sehingga meningkatkan permintaan beras di pasar domestik. Kondisi ini memberikan keuntungan bagi konsumen sebesar Rp2.083,46 miliar. Kebijakan peningkatan kredit pertanian yang diberikan kepada produsen padi agar menjadi insentif petani untuk meningkatkan produksi padi, tetapi hal tersebut tidak menguntungkan petani tetapi menguntungkan produsen beras. Hal ini menunjukkan bahwa peningkatan produksi padi tidak
Tabel 2 Dampak kebijakan perberasan pada kesejahteraan masyarakat 2010-2014

\begin{tabular}{lrrrr}
\hline \multicolumn{1}{c}{ Indikator } & \multicolumn{4}{c}{ Simulasi (Rp miliar) } \\
\cline { 2 - 5 } kesejahteraan & 1 & 2 & 3 & 4 \\
\hline Surplus & & & & \\
produsen & $-1317,47$ & $-1365,49$ & 2872,64 & 192,43 \\
$\begin{array}{l}\text { Surplus } \\
\text { konsumen }\end{array}$ & 2083,46 & 2187,96 & $-3858,61$ & 422,27 \\
Jumlah & 766,00 & 822,46 & $-985,97$ & 614,70 \\
\hline
\end{tabular}

menjamin keuntungan bagi petani, jika harga jual padi tersebut tidak dapat dikendalikan oleh pemerintah melalui kebijakan penjaminan harga gabah.

Kebijakan peningkatan subsidi pupuk (simulasi 2) memberikan dampak yang sama dengan kebijakan peningkatan kredit pertanian, yaitu memberikan keuntungan bagi konsumen tapi merugikan produsen karena penyaluran pupuk yang kurang efektif (Suryana et al. 2016). Peningkatan subsidi pupuk menyebabkan peningkatan produksi padi, tetapi dengan peningkatan produksi padi mengakibatkan harga gabah di tingkat petani turun sehingga merugikan produsen. Kerugian produsen terlihat dari penurunan surplus produsen sebasar Rp1.365,49 miliar. Berbeda dari produsen, penurunan harga gabah mengakibatkan penurunan harga beras eceran sehingga meningkatkan permintaan beras di pasar domestik. Kondisi ini memberikan keuntungan bagi konsumen terlihat dari surplus konsumen sebesar Rp2187,96 miliar. Penerapan kebijakan tunggal berupa subsidi pupuk tidak dapat meningkatkan kesejahteraan petani, padahal kebijakan tersebut ditujukan kepada petani untuk meningkatkan produksi padi sehingga keuntungan petani bertambah. Produksi padi sudah meningkat sebesar 164.100 ton tetapi harga jual gabah menurun sehingga bukan keuntungan yang didapat petani tetapi kerugian yang diterima petani. Kondisi ini menunjukkan bahwa penerapan jaminan harga sangat diperlukan bagi petani untuk meningkatkan kesejahteraannya.

Kebijakan jaminan harga berupa peningkatan HPP (simulasi 3) mengakibatkan peningkatan harga gabah pada tingkat petani sehingga menjadi insentif bagi petani untuk meningkatkan produksi padi. Peningkatan harga gabah pada tingkat petani dan produksi padi memberikan keuntungan bagi produsen yang terlihat pada surplus produsen sebesar Rp2.872,64 miliar. Berbeda dari produsen, peningkatan HPP mengakibatkan harga gabah meningkat sehingga harga beras eceran meningkat walaupun penawaran beras meningkat. Peningkatan harga gabah lebih efektif memengaruhi harga beras eceran dibandingkan dengan peningkatan penawaran beras. Peningkatan harga beras eceran mengakibatkan permintaan beras menurun. Kondisi ini mengakibatkan konsumen merugi yang terlihat pada penurunan surplus konsumen sebesar Rp3.858,61 miliar. Kebijakan penjaminan harga berupa peningkatan HPP sangat efektif untuk meningkatkan kesejahteraan produsen, tetapi menjadi tidak efektif untuk meningkatkan kesejahteraan konsumen beras.

Kebijakan domestik berupa peningkatan HPP, kredit pertanian, dan subsidi pupuk memiliki efek yang 
berbeda pada surplus produsen dan konsumen. Peningkatan HPP memberikan keuntungan bagi produsen tapi merugikan konsumen, sedangkan kebijakan kredit pertanian dan subsidi pupuk memberikan keuntungan bagi konsumen tetapi merugikan produsen. Hal ini menunjukkan bahwa penerapan kebijakan tunggal tidak mampu memberikan keuntungan bagi kedua belah pihak. Alternatif paket kebijakan berupa peningkatan HPP, peningkatan kredit pertanian, dan peningkatan subsidi pupuk (simulasi 4). Peningkatan kredit pertanian dan peningkatan subsidi pupuk memberikan insentif bagi petani untuk meningkatkan produksi padi, sedangkan peningkatan HPP mengakibatkan peningkatan harga gabah di tingkat petani sehingga kondisi ini memberikan keuntungan bagi produsen yang terlihat dari surplus produsen sebesar Rp192,43 miliar. Peningkatan produksi beras mengakibatkan peningkatan penawaran beras di pasar domestik sehingga mengakibatkan harga beras eceran turun. Penurunan harga beras eceran mengakibatkan peningkatan permintaan beras. Kondisi ini memberikan keuntungan bagi konsumen, yang terlihat dari surplus konsumen yang meningkat sebesar Rp422,27 miliar. Alternatif paket kebijakan sesuai dengan simulasi 4 dapat memberikan keuntungan bagi produsen maupun konsumen beras sehingga kesejahteraan petani dan konsumen beras meningkat. Pemerataan kesejahteraan tersebut merupakan kondisi yang diinginkan oleh kedua pihak, sehingga harus menjadi fondasi utama bagi pemerintah untuk membuat kebijakan yang memihak ke semua lapisan masyarakat.

\section{KESIMPULAN}

Kondisi pasar beras Indonesia baik di tingkat petani maupun di tingkat konsumen sangat bergantung pada kondisi permintaan dan penawaran yang diakibatkan oleh perubahan produksi beras domestik dan jumlah impor beras Indonesia. Perubahan kebijakan perberasan berupa peningkatan Harga Pembelian Pemerintah (HPP), peningkatan kredit pertanian, dan peningkatan subsidi pupuk mengakibatkan peningkatan produksi padi sehingga meningkatkan penawaran beras di pasar domestik. Perubahan penawaran beras mengakibatkan perubahan harga beras eceran sehingga memengaruhi perubahan jumlah permintaan beras di pasar domestik. Surplus produsen dan konsumen dipengaruhi oleh kondisi pasar beras Indonesia. Surplus produsen akan dicapai jika pemerintah menerapkan kebijakan jaminan harga berupa HPP, sedangkan surplus konsumen akan dicapai jika pemerintah menerapkan kebijakan peningkatan subsidi input berupa kredit pertanian dan subsidi pupuk. Penerapan paket kebijakan kebijakan peningkatan HPP, peningkatan kredit pertanian, dan peningkatan subsidi pupuk mampu meningkatkan kesejahteraan produsen dan konsumen beras. Hal ini menunjukkan bahwa kebijakan tunggal tidak mampu meningkatkan kesejahteraan produsen maupun konsumen.

\section{DAFTAR PUSTAKA}

Abidin MZ. 2015. Dampak Kebijakan Impor Beras dan Ketahanan Pangan dalam Perspektif Kesejahteraan Sosial. Jurnal Sosio Informa. 1(3): 213-230.

Akhmad. 2014. Dampak Kebijakan Tarif Impor Beras terhadap Surplus Produsen dan Konsumen. Jurnal Bappenas. 20(1): 14-31.

[BPS] Badan Pusat Statistik. 2015. Laju Pertumbuhan Penduduk Indonesia. [internet]. [diunduh 2016 Juni 24]. Tersedia pada: https://www.bps.go.id/linkTabelStatis/view/id/1268.

[BPS] Badan Pusat Statistika. 2016. Produksi Beras Indonesia [internet]. [diunduh 2016 Juni 24]. Tersedia pada: https://www.bps.go.id/site/resultTab.

Busnita SS. 2016. Rice Price Volatility, its Driving Factors and the Impact of Climate Chage on Paddy Production and Rice Price in Indonesia. Jurnal of Agricultural and Applied Economics. 41(2): 427-431.

Dabukke FBM, Iqbal M. 2014. Kebijakan Pembangunan Pertanian Thailand, India, dan Jepang serta Implikasinya bagi Indonesia. Jurnal Analisis Kebijakan Pertanian. 12(2): 87-101. https://doi.org/10.21082/akp.v12n2.2014.87-101

Edi, Sirojuzilam, Rahmanta. 2014. Analisis Integrasi dan Volatilitas Harga Beras Regional Asean terhadap Pasar Beras Indonesia. Jurnal Ekonomi. 17(2): 77-91.

Hidayat NK. 2012. Dampak Perubahan Harga Beras Dunia Terhadap Kesejahteraan Masyarakat Indonesia pada Berbagai Kondisi Transmisi Harga dan Kebijakan Domestik. Jurnal Sosial Ekonomi Pertanian. 8(1): 63-71.

Koutsoyiannis. 1977. Theory of Econometrics: An Introductory Exposition of Econometric Methods. Second Edition. London (EN): The MacMillan Press Ltd.

Mardianto S, Mewa A. 2004. Kebijakan Proteksi dan Promosi Komoditas Beras di Asia dan Prospek Pengembangannya di Indonesia. Jurnal Analisis Kebijakan Pertanian. 4(2): 340-353.

Miranti A, Syaukat Y, Harianto. 2016. Pola Konsumsi Pangan Rumah Tangga Petani di Provinsi Jawa Barat. Jurnal Agro Ekonomi. 34(1): 67-80. https://doi.org/10.21082/jae.v34n1.2016.67-80

Musianto LS. 2002. Perbedaan Pendekatan Kuantitatif dengan Pendekatan Kualitatif dalam Metode Penelitian. Jurnal Manajemen dan Kewirausahaan. 4(2): 123-136.

Nuryanti S. 2005. Analisis Keseimbangan Sistem Penawaran dan Permintaan Beras di Indonesia. 
Jurnal Agro Ekonomi. 23(1): 71-81. https://doi.org/10.21082/jae.v23n1.2005.71-81

Office of the United States Trade Representative. 2015. Re: Comments Regarding the 2015 National Trade Estimate Report on Foreign Trade Barriers [internet]. [diunduh 2016 April 27]. Tersedia pada: https://www.usarice.com/docs/defaultsource/tradepolicy/usa-rice-nte-2015-submission.pdf?sfvrsn=2.

Rahmasuciana DY, Darwanto DH, Masyhuri. 2015. Pengaruh Pengadaan Beras dan Oprasi Pasar terhadap Harga Beras dalam Negeri. Jurnal Agro Ekonomi. 26(2): 129-138. https://doi.org/10.22146/agroekonomi.17266

Riyadi DM. 2002. Permasalahan dan Agenda Pengembangan Ketahanan Pangan: Tekanan penduduk, degradasi Lingkungan dan Ketahanan Pangan. Pusat Dalam: Prosiding Studi Pembangunan dan Proyek Koordinasi Kelembagaan Ketahan Pangan.

Rosandi R. 2016. Respon Stok Beras Indonesia dalam Masyarakat Ekonomi ASEAN: Analisis Dampak Produksi, Tenaga Kerja, dan kesejahteraan [Tesis]. Bogor (ID): Institut Pertanian Bogor.

Sapuan. 1999. Perkembangan Manajemen Pengendalian Harga Beras di Indonesia 1969-1999. Jurnal Agro Ekonomika. 29(1): 55-63.

Septiadi D. 2016. Dampak Kebijakan Perberasan Terhadap Pengentasan Kemiskinan di Indonesia [Tesis]. Bogor (ID): Institut Pertanian Bogor.
Sudaryanto T, lqbal M, Kustiari R, Dermoredjo SK, Muslim C, Saputra YH. 2016. Tingkat Dukungan Domestik untuk Sektor Pertanian Indonesia. Jurnal Analisis Kebijakan Pertanian. 14(1): 73-82. https://doi.org/10.21082/akp.v14n1.2016.73-82

Suryana A, Agustian A, Yofa RD. 2016. Alternatif Kebijakan Penyaluran Subsidi Pupuk bagi Petani Pangan. Jurnal Analisis Kebijakan Pertanian. 14(1): 35-54.https://doi.org/10.21082/akp.v14n1.2016.35 $-54$

[USDA] United States Department ofAgriculture. 2015. Rice Outlook [internet]. Washington DC (US): [diunduh 2016 April 27]. Tersedia pada: https://www.ers.usda.gov/webdocs/publications/rcs 15b/51753_rcs-15b.pdf.

Wahid NH. 2015. Latar Belakang Kebijakan Impor Beras Indonesia dari Thailand periode 2009-2011 [Skripsi]. Jakarta (ID): UIN Syarif Hidayatullah Jakarta.

Widiarsih D. 2012. Pengaruh Sektor Komoditi Beras Terhadap Inflasi Bahan Makanan. Jurnal Sosial Ekonomi Pembangunan. 2(6): 244-256.

Zaeroni R, Rustariyuni SD. 2016. Pengaruh Produksi Beras, Konsumsi Beras, dan Cadangan Devisa terhadap Impor Beras di Indonesia. Jurnal EP Unud. 5(9): 993-1010. 